\title{
Space and Staging in the Digby Mary Magdalen and Pericles, Prince of Tyre
}

Pericles is a natural for a full-scale promenade production, in which the audience would follow the characters to and fro across a playing-space that would be the map of the north-eastern part of the Mediterranean, in which the journeying of the characters and the action would also be the journeying of the audience as we see the action at a place that spatially represents its positioning, their journey as our journey, our thoughts piloting them around the theatre from port to port. ${ }^{1}$

The connections between medieval literature and Shakespeare's romances are most visible in the self-consciously emblematic and archaic Pericles (1609). The most obvious medieval element is the use of Gower as Chorus and source, but Knight, Felperin, Hoeniger, and, more recently, Womack and Mowat note the play's dramaturgical connections with miracle, saints', and morality plays. ${ }^{2}$ Gower's role recalls the medieval Presenter; the play's characterization recalls morality Virtues and Vices; the miraculous restorations of the final acts recall several saints' tales. ${ }^{3}$ One of the most striking parallels is with the fifteenth-century Digby Manuscript play Mary Magdalen: the tale of Pericles, Thaisa, and Marina is nearly identical to the tale of the King of Marcylle and his Queen in the saint's play. ${ }^{4}$ The Mary Magdalen is not a source for Pericles, however; instead, the two plays share a common source in the interconnected roots of romance and hagiography. Greek romances, including the tale of Apollonius of Tyre, the source of Pericles, influenced the development of saints' legends, including the legend of Mary Magdalen. As Womack puts it, 'it is not that the Mary Magdalen influenced Pericles, but that the source of Pericles influenced the source of Mary Magdalen'. 5

Critics discuss the two plays, separately and together, and have effectively established why these dramas tell the same story. What has gone largely unexamined, however, is how they do so. The two plays provide an unusual opportunity for a comparison of the dramaturgical work of two periods: they 
present the same tale, told to two different audiences, in two different playing spaces by dramatists working under two different sets of dramatic expectations. This paper will focus on the plays' representation of space on two different stages: the place-and-scaffold playing space for Mary Magdalen and the unlocalized stage of the Globe for Pericles. Space is central to both plays, because travel is central to the tale, and because the two playing spaces are radically different from one another. The plays grapple with the challenge of how to present a geographically and temporally sprawling story in a limited performance space. In both, the physical and conceptual layout of that performance space structures the solution to the problem. For all drama, the physical space of performance and the performance conventions developed for it dictate dramatic structure, but in the case of Mary Magdalen and Pericles, the two stages provide radically different perspectives to each audience. The stage space of Mary Magdalen is a physical map of the play world, and the audience has a god's-eye view of the actors moving from place to place within it; the stage space of Pericles is the unlocalized stage of the Globe, on which locale must be identified with each entry. These specificities mean that, as audience members, we can see where we are in Mary Magdalen, but we always have to be told where we are in Pericles. The clarity of one space and the contingency of the other have a direct effect on the nature of the tales told within them; although they both tell the same tale, its affective function shifts dramatically between the two plays.

I need to make a number of caveats before I begin. First, the different performance spaces are obviously not the only reasons for the differences between the two plays; Mary Magdalen is a pre-Reformation sacred tale, staged in open performance space as an act of communal devotion as well as entertainment, and Pericles is a secular one performed for a paying protestant audience within a closed theatre. Second, any discussion of the staging of either play must be speculative; although most criticism assumes a place-and-scaffold production, no independent evidence exists for the staging of Mary Magdalen, and the text of Pericles is corrupt, making it difficult to determine staging and structure. ${ }^{6}$ As well, we can attribute much of Pericles's episodic dramatic structure to its genre - romance - or its source, Gower's Confessio Amantis (1393). Several popular dramatic romances, such as Clyomon and Clamydes (1583), Mucedorus (1598), and The Four Prentices of London (1615), and parodies, such as The Knight of the Burning Pestle (1609), share Pericles's loose, episodic structure — seemingly the default structure for dramatic romance. Gower's poem has a similar episodic structure, and 
Hoeniger notes the ways in which the play's structure parallels that of the poem. ${ }^{7}$ Finally, critics have long acknowledged that cultural memory of preReformation staging practices underpins the dramaturgical structure of Renaissance plays. These arguments stretch from David Bevington's tracing of structural origins, through Robert Weimann's argument that the representational positions of locus and platea were adapted to the open stage of the public theatres, to more recent suggestions such as Michael O'Connell's that 'cultural memory' of saints' plays underlies the archaism of Pericles. ${ }^{8} \mathrm{I}$ do not propose to argue for such a causal connection between these two plays; I only want to compare them in order to suggest some ways theatrical space helps to determine meaning. ${ }^{9}$

To say that the tales of Pericles and the King of Marcylle are all but identical is no exaggeration. The same key events occur in both plays: both couples undertake sea voyages, both queens die in labour during a storm, and both men are forced to bury their wives at sea, Pericles throwing Thaisa overboard in a sealed chest and Marcylle leaving his Queen on a rock in the Mediterranean. Both kings also abandon their newborn infants: Pericles leaves Marina 'at careful nursing' in Tarsus (3.1.78) and Marcylle leaves his baby beside the body of its dead mother. ${ }^{10}$ Finally, both men are reunited with their miraculously restored wife and child, although this restoration is more explicitly miraculous in the saint's play than in Shakespeare's play, since the Queen of Marcylle and her infant are preserved in a kind of spiritual suspended animation, and simply wake up upon the return of the King's ship to the rock, two years later. ${ }^{11}$ The more complex restoration of Marina and Thaisa takes up all of Pericles acts 4 and 5; Cleon and Dionyza, Marina's foster parents, tell Pericles that Marina has died when in fact she has been abducted by pirates, who have sold her into a brothel. Fortune and the sea lead Pericles to find Marina in Mytilene, and a vision of Diana then sends him to Ephesus to find his wife, who has become a vestal in the goddess's temple.

The similarities between the two plays go beyond plot into genre and structure. Both are wide-ranging romances, covering vast temporal and geographic distances, and both are tales of travel and pilgrimage. Both have multiple settings: the Digby play contains twenty-one locales, and Pericles has seven settings — six kingdoms and the sea itself. Both centre on seavoyages and both stage shipboard scenes: the Digby play uses a pageant ship to transport the saint and her followers between Marcylle and the holy land, and Pericles presents two climactic scenes on shipboard. And the travels of their protagonists structure both plays, although the two have very different 
motivations for movement. Those of Mary Magdalen are spiritual: Mary's travels are missionary voyages directed by Christ, and her convert, the King of Marcylle, makes a pilgrimage to the holy land in search of baptism. Pericles's motives are secular: he is driven first by desire for Antioch's daughter and then by terror of Antioch's wrath. A series of storms, shipwrecks, and losses structure his subsequent voyages and eventually drive him to a psychological wreck from which he must be rescued, Lear-like, by the daughter he has abandoned.

The dramatic structure of Mary Magdalen clearly builds on the structure of its playing space. The play world itself, built of scaffolds ranged around an open playing space, is a map of physical and spiritual power upon which the characters move: physical travel between stations enacts the pilgrimages of Mary and her disciples. The spatial logic of the scaffolds helps to integrate the action of the play, which is a blend of biblical history, moral allegory, and romance, and it helps the audience perceive parallels in actions that occur over time and in space. The audience is able to see all available playing spaces: characters move between the loca (scaffolds) and over the platea (place) in patterns that help define and explain the world. In some cases, the possible use of the same station for different actions stresses parallels between those actions. For example, if the structure that serves for Lazarus's tomb (1.840 sd) and Christ's sepulchre (1011) represents the 'roch' (1.1784) in the platea on which the King of Marcylle abandons his wife and child, then leaving the Queen's body there makes sense spatially, if not narratively. According to the narrative, the rock is in the middle of the Mediterranean, while Lazarus's tomb and Christ's sepulchre are in the holy land. But if, in terms of the playing space, the same playing structure represents the three locations, the play's three resurrections are visually tied together for the audience. Having seen Christ and Lazarus both rise from the dead in the same spot, the audience would be able to deduce the eventual fate of the play's third 'corpse', even if some of the audience did not know the Magdalene legend. This recognition, together with the King's prayer over the miraculously preserved body of his dead Queen (1892-8), renders sacred the romance resurrection of the Queen and her child. Her miraculous preservation parallels and attests to her miraculous vision of the holy land and experience of baptism while entranced (1905-10). Similarly, the arbour in the platea in which Mary wakes to repentance by the Angel (588-610) is analogous to the garden in which she meets the risen Christ (1061-95) and the wilderness from which she ascends to heaven at the play's close (1989). 
All three are natural spaces in which the heroine meets heavenly emissaries and undergoes spiritual and physical transformation; they could easily be presented by the same playing space. The play contains numerous such parallels and oppositions: the tavern in which Mary falls to her fleshly lover Curiosity (491-546), allowing her to be conquered by the Seven Deadly Sins, opposes the house of Simon, where she meets her spiritual lover Christ and is cleansed of seven devils (sd 691). Physical, visible structures help link together the moral significance of the play's events; the audience knows what is likely to happen within each such structure. The scaffolds give physical form to the play's moral topography.

The logic of place-and-scaffold space also frames the spiritual world of the play. As Jerome Bush notes, the loca all belong to 'well-defined fictive place[s] or institution[s]' (139), all connected with worldly or spiritual power, while Christ, the disciples, and the messenger angels appear on the platea, the undefined place of vision, resurrection, and pilgrimage. ${ }^{12}$ The play anchors in place temporal powers: the script calls for 'houses' for the Emperor in Rome and for Herod and Pilate in Jerusalem. The loca of these temporal lords find parallel in those of the World, the Flesh, and the Devil: the powers of the world, both temporal and spiritual, have earthly habitations. The Castle Magdalen, the home of Mary, her father Cyrus, and her siblings Lazarus and Martha, is ranged along with these, although it has slightly different functions. It stands allegorically as an analogue for Mary's soul, since the Seven Deadly Sins besiege it before her fall (sd 439). But it also allies her family with worldly powers: the boasts that Cyrus delivers (49-85) parallel those of the Emperor that open the play (1-18). It is therefore a place Mary must leave, and once she becomes Christ's follower, she does. She returns to the Castle to convert her brother and sister, and to stage Lazarus's death and resurrection, but after her confrontation with the risen Christ at the tomb, Mary abandons the Castle for missionary travel to Marcylle and hermetic meditation on the platea space. ${ }^{13}$

The treatment of the loca also enacts the limited scope of worldly power: the true power in this play world belongs to heaven, to which worldly and infernal powers are inferior, no matter how loudly they boast. The introductory rants of Caesar, Herod, Pilate, Cyrus, World, Flesh, and Devil work to undercut one another. Each of them claims supreme authority and demands obeisance from the audience, but they cannot all be the supreme leader of the earth. As Bush notes, the scaffolds also limit the capacity of their occupants to act: the temporal powers are trapped on their scaffolds and within 
history. ${ }^{14}$ They can only send messengers between themselves, as at the opening of the play, when a messenger travels from Rome to Herod and then to Pilate (114-264), a sequence repeated after the resurrection, when a messenger is sent from Pilate to Herod to Rome (1269-1335). None of these temporal lords influences the events of the play, or has any direct interaction with any other character. The infernal powers, the World, the Flesh, and the Devil, are less tethered to their scaffolds but are no more effective. The Devil and the Flesh, accompanied by Envy, Wrath, Luxury, Gluttony, and Sloth, move from their own scaffolds to World's house and join Pride and Covetousness in attacking Magdalen Castle (305-439), but they are ultimately driven back to their loca upon Mary's repentance. The EETS editors suggest that the houses of World, Flesh, and Devil are staged consecutively (304 sd), implying that the figures simply void and fill the same scaffold, which would be more efficient than building three separate stages. But no matter how many scaffolds are used to represent these locales, the evil figures are confined to them; in fact, after Mary's conversion the Devil seems to order his demons to board the Seven Deadly Sins up in World's house and set it on fire. ${ }^{15}$ The Temple of Mahownd at Marcylle, blasted by fire from heaven when Mary prays for a sign (sd 1562), shares this fiery fate. If both World's scaffold and the Temple stand as burnt wrecks for the remainder of the play, they would be visual markers of divine action in the world, and analogues of the harrowed and defeated hell the Devil describes (963-92). They are, like so many other playing structures, visual signals of spiritual action.

Most importantly, the playing space of Mary Magdalen is a clearly structured spiritual and physical map of the world. Because all portions of the space are visible to the audience, spectators are able to grasp the structures and implications of the space at a glance. As the characters move between the scaffolds and across the place, their movements make plain their loyalties and associations: characters that share sympathies and motivations visit one another, send messengers to one another, and act together. Despite the complex action of the play, the playing space acts as a map, physical and spiritual, of the characters' progress. The audience cannot get lost; in fact, the audience has a bird's-eye view similar to the perspective of Christ on the heaven scaffold.

The space of Pericles is considerably more ambiguous. Of course, the play is set in the real space of the north-eastern Mediterranean, rather than the mixed spiritual/physical setting of Mary Magdalen. This connection to physical geography should help the audience envision the space of the action. 
But even for a reader, even one armed with a map of the Hellenized eastern Mediterranean, Pericles's voyages are hard to trace, since the locations of the cities, most notably Pentapolis, are hard to pin down. ${ }^{16}$ In performance, the dramaturgical space of Pericles is even more puzzling. The play has more locales than any other in the canon, and the action continually shifts between them. With the exceptions of scenes 2 and 3 of act 1 both set in Tyre, and the Pentapolis episode of act 2, no two successive scenes are set in the same place. ${ }^{17}$ The unlocalized stage of the Globe dictates the representation of this space: while Mary Magdalen has multiple locations visible to the audience at one time, Shakespeare and Wilkins must represent their settings sequentially. ${ }^{18}$ Although the platform stage can represent any locale at any point in time, in order for it to function effectively, the audience must also remember where the action has come from and where it is going, which is difficult to do when cutting between locations or across time. While the movements of characters between iconic locations in the Mary Magdalen provide information that allows the audience to interpret the meaning of that movement, in Pericles the locations themselves shift, and the map of the action must be built within the audience's memory. We lack the spatial logic of the saint's play because we lack the visual overview that the place-andscaffold staging provides.

This element of the play produces two effects. First, as a theatrical experience, Pericles is fluid; the six cities succeed one another in waves. This feature stems from the stage stretching to cover the range of the tale, but the result is that the audience shares Pericles's sense of being sea-tossed, perpetually in transit. Second, this rootlessness impacts the play's affective impact - the feeling of dislocation produced at least in part by the contingent stage space. The play associates this contingent space in various ways with the sea, which is the play's dominating metaphor as well as its central location. The tale's roots lie in the voyages and shipwrecks of classical romance, which is why the sea is the centre of the play's action, metaphorical and real. ${ }^{19}$ Pericles is in constant motion, shuttling from port to port, and his characteristic movement is away, out to sea, 'beyond "the edge a' th' shore" or on the edge'. The play magnifies the importance of the sea through the latter's association with Marina: the redemptive child is a product 'of no shores' — 'born at sea, buried at Tarsus / and found at sea again' (5.1.186-7) — birthed by a supposedly dead mother whose monument is 'the belching whale / And humming water' (3.1.62-3). Both her birth and restoration take place on shipboard: Shakespeare's choice to stage her reunion with her father on board 
his anchored ship rather than ashore stresses her link to the sea. The figure of Gower acts as the play's anchor, repeatedly tethering us to the narrative, explaining where we have been and where we are going: as Peter Holland puts it, extending the metaphor, Gower is a pilot, one who knows the waters of the tale and can serve as a guide. ${ }^{21}$ Such nautical metaphors animate the play: Pericles's grief is a 'tempest which his mortal vessel tears / And yet he rides it out' (4.4.29-30) and he is almost 'drown[ed] by [the] sweetness' of a 'great sea of joys' (5.1.182-4) when reunited with Marina. Thus, Shakespeare makes the sea the play's principal symbol of the 'ungrounded contingency', both physical and psychological, that drives Pericles's wanderings. ${ }^{22}$ The contingency of the platform stage is the dramaturgical equivalent of this metaphor: the fluidity of the staging supports the fluidity of the narrative itself. While watching the play the audience is, like Pericles, at sea, always in danger of being lost in the tale. Although the narrative is the same as that of Marcylle in Mary Magdalen, the position of the audience and the effect that the tale has on them inverts the experience of the saint's play.

The experience of audiences at modern productions, who have little difficulty following the play's shifts of locale, seems to contradict this thesis that the play deliberately trades on its contingent locations. Most modern productions follow Elizabethan practice in using a bare stage and marking locale with costumes and hand props; however, they still provide a much richer set of location cues than were available at the Globe. ${ }^{23}$ Even minimalist productions mark settings - subtly with lighting and soundtracks, explicitly with costumes and props - and such cues play a role similar to the placeand-scaffold performance space of the Mary Magdalen, enabling audiences to locate themselves visually. Minimalist productions such as those of the Royal Shakespeare Company (Hands 1969 and Daniels 1979) were played on bare stages, but used emblematic costumes to mark spaces and characters: in Daniel's production Antiochus and Simonides, both played by the same actor, wore black and white respectively. ${ }^{24}$ Other productions have staged the play as a 'play-within' presented by inhabitants of spaces ranging from a transvestite brothel (Robertson 1973), to a hospital/institution (Bourne 2003) and a refugee camp (Ninagawa 2003). ${ }^{25}$ In these stagings, the setting of the outer play fixes the stage itself: it remains the brothel, camp, or institution, and the inmates' travels within it are imaginary. Productions which do actively shift locales normally mark each as an identifiable space: Grief (New York Shakespeare Festival 1991) set Antioch in pre-history, Pentapolis in Arthurian England, and Mytilene in 'a cross between Bangkok ... 
and Miami Beach'. ${ }^{26}$ Lloyd's 1994 National Theatre production created six distinct imaginary cultures with different languages, clothing, and music, and Rubin's 2003 Stratford Festival production moved the action between Japan, Indonesia, Arabia, and Greece via costumes and light. ${ }^{27}$ One interesting variant, Banno's Washington Shakespeare Company production of 1998, used an empty warehouse to mount a place-and-scaffold production, moving the action between six sets representing Antioch, Tyre, Pentapolis, Ephesus, Mytilene, and the sea, with Tarsus located in the middle of the space. ${ }^{28}$ This production - as well as the comment by Holland used as an epigraph to this paper - suggests that one way to clarify the space of Pericles is to stage the play as if it were Mary Magdalen.

In modern productions, the active intervention of designer, director, and scenographer creates a frame for the audience to visually locate themselves: the need to combat potential confusion presented by the swift changes of locale supports the argument that such confusion exists, at least in potential, within the text. Many scenographic elements of the modern theatre were obviously not available in the Globe, but those that were, such as music and costume, were deployed differently. Modern productions use music as scene setting, but although music is central to the action of the play, heralding Diana's appearance and seemingly causing Thaisa's resurrection, the play-text gives no sense that it marks location. Similarly, although the company could have linked the play's different locales through coherent costume design, it is unlikely that they did so, as costume seems to have denoted rank or role rather than locale. Therefore, we should not assume that the visual ease with which contemporary audiences follow the movement of the action from place to place reflects the experience of audiences in the Globe.

The location devices embedded in the text of Pericles are those common to the Renaissance stage: locale is established by naming a place, by emblematic props, and by association with certain characters. Gower, the Chorus, also identifies locations, narrates events, moves action through time and across space, and glosses the dumb shows that mark key events: as his role is the most complex I will deal with him last. ${ }^{29}$ The most common location device is the simplest: naming a locale at the opening of a scene. Suzanne Gossett's Arden edition has nineteen scenes, punctuated by Gower's eight chorus speeches; twelve of these scenes name their location. Gower makes such references six times at the conclusion of his chorus speeches: 'This Antioch, then' (1.0.17); 'In your imagination hold / This stage the ship' (3.0.58-9); 'now to Marina bend your mind, / Whom our fast-growing scene must find / At 
Tarsus' (4.0.5-7); 'And think you now are all in Mytilene' (4.3.51); Pericles 'is arrived / Here where his daughter dwells' (5.0.14-15); 'At Ephesus the temple see / Our King and all his company' (5.2.17-18). Characters locate the action twice: Thaliard enters on 'So this is Tyre, and this the court' (1.3.1), and the Pander on 'Mytilene is full of gallants' (4.2.3). Three more scenes establish locales through inference: when Pericles enters in act 1 scene 2 , he dismisses the lords who enter with him on 'Let none disturb us' (1.2.1), and the royal we identifies the location, although we have not seen Tyre before. Similarly, the entrances of Helicanus (2.4.1) and of Cleon and Dionyza (3.3.1; 4.3.1) identify Tyre and Tarsus, as the cities are associated with these characters. Such association also underpins Gower's seemingly unnecessary explanation of Helicanus's reasons for joining Pericles on the trip to reclaim Marina (4.4.13-16): because Helicanus has been the marker for Tyre, his presence elsewhere could confuse matters.

These relatively passive location techniques are pervasive enough to be invisible. But our dependence on them becomes noticeable when such information is withheld, particularly in a play where we are always somewhere new; Pericles employs this technique three times. Twice the audience is kept guessing for only a few lines: Cleon identifies 'this Tarsus o'er which I have the government' (1.4.21) after he and Dionyza have lamented for twenty lines, and Cerimon and his visitors have forty-three lines of dialogue before the First Gentleman declares that Cerimon has 'through Ephesus poured forth your charity' (3.2.43). The delay is not great in either case, and in any event the dramatic function of both places is more important than their names: Cleon's lines establish Tarsus's suffering, which Pericles will alleviate, and Cerimon establishes Ephesus as a place of healing, which will resurrect Thaisa. But the third example, Pericles's arrival at Pentapolis, deliberately leaves the audience in the dark for the first ninety-five lines of the scene (six minutes of playing time in the BBC video). Gower's speech, which describes Pericles's flight from Tarsus and subsequent shipwreck, ends on 'Fortune, tired with doing bad, / Threw him ashore to give him glad' (2.0.37-8). Like Pericles himself, the audience only knows that he is 'ashore', but not where. The conversation of the fishermen drops two hints as to the locale - the name King Simonides (2.1.44), which Pericles repeats (2.1.45), and the reference to 'our country of Greece' (2.1.66) — but we are not told where we are until Pericles has been wrapped in the fisherman's gown and the two junior fishers have left to draw up their net. Importantly, Pericles does not ask where he is; the Fisherman prompts him with 'Hark you, sir, do you know 
where ye are?' (2.1.93). Only on Pericles's response, 'Not well', does the fisherman answer 'Why, I'll tell you. This is called Pentapolis, and our king, the good Simonides' (2.1.95). The stress on Pericles's ignorance emphasizes that of the audience; like Pericles, we know 'not well' where we are. Withholding this information for as long as this scene does forces us to recognize our dependence on the location cues provided by text and performance, and the instability of our position: it is almost as if Shakespeare is pointing out the uncertainty of location in the play.

Visual and aural cues to location are harder to see in the script. Certainly, the King's Men used hand props and costumes to mark locale or period in some ways. Gower is recognizably medieval in speech, and probably was also in costume; the woodcut on the title page of Wilkins's The Painfull Adventures of Pericles Prince of Tyre presents one possible version of this costume, or, alternately, the company may have copied the effigy on Gower's tomb, which lay in St Mary's Southwark. ${ }^{30}$ The chivalric pageantry of Pentapolis is also presumably psuedo-medieval or courtly. Mytilene is ambiguous, but the Bawd's praise of Marina's clothes implies that they differentiate her from the brothelkeepers (4.2.125-6), either geographically or by rank. As Gossett points out, 'a striking contrast between her appearance and her position' would explain the speed of Lysimachus's recognition that Marina does not belong where she is. ${ }^{31}$ Most costumes, however, denote social roles or, less frequently, psychic states. Stage directions like 'Enter Pirates' ( $4.1 .87 \mathrm{sd}$ ) imply a visual shorthand in the costumes of pirates, fishermen, and sailors; visual shorthand for shipwreck and mourning is also clearly at work in directions like 'enter Pericles wet' (2.1.1 sd) and 'puts on sackcloth' (4.4.22 sd). ${ }^{32}$

Props mark settings as well, sometimes mimetically; directions such as 'Enter Pericles on shipboard' (3.1.1 sd) suggest a common set of visual and auditory markers for shipboard scenes. In fact, Marina's description of her father's heroics in the storm - struggling with ropes amongst dripping mariners to the accompaniment of the boatswain's whistle and the master's calls (4.1.51-63) - may recall the actual staging of act 3 scene $1 .{ }^{33}$ More commonly, though, props emblematically mark locations. The severed heads mark Antioch as a place of death and tyranny, and the triumph of knights and their devices associates Pentapolis with chivalry and virtue (2.2.16-45). The last spectacle deliberately folds chivalric romance into the framing Greek tale; the relation between the two forms is visually represented by Pericles's rusty armour, produced by the literal drowning of the armour of chivalric romance in the sea of Greek romance. The rusty armour also allows 
a glimpse of Simonides's judgment; when the lords jeer at Pericles's shabby appearance (2.2.53), he rebukes them with 'Opinion's but a fool, that makes us scan / The outward habit for the inward man' (2.2.54-5). Pentapolis is a place where inner virtue is recognized and respected, which opposes it to the corrupt hypocrisy of Antioch. Stage images formed by gesture and posture mark locations in a similar way: Cleon's entry line 'shall we rest us here ... [and] relate tales of others' griefs' (1.4.1-2) suggests that he and Dionyza sink to the ground in a posture of despair. ${ }^{34}$ If they were still wearing rich garments, as is possible given the discussion of Tarsus's previous abundance (1.4.26-7), the image would mark the city as a place of wealth brought low. Likewise, Pericles's final revival from his unkempt catatonia is an emblematic as well as an actual awakening from despair, which his formal presentation as a stage image of grief emphasizes $(5.1 .29 \mathrm{sd})$.

Finally, the most obvious location device in the play is Gower himself. He situates us in more ways than the geographic, since his opening speech locates him in relation to the tale he tells and the theatre in which he tells it. Gower is not just a chorus, but the author of the play's source text, the 'most sustained literary allusion to be found in Shakespeare'. ${ }^{35} \mathrm{He}$ is the play's first resurrection (1.0.2-4), a medieval poet come to life in order to work with contemporary actors to present a much older legend: 'a song that old was sung' (1.0.1). ${ }^{36}$ As such, he is distanced from both the classical tale he tells and the Renaissance audience he tells it to. But paradoxically, Gower also shares the space of the audience; like all chorus figures he is explicitly located on the stage of the Globe, telling the tale. As he puts it, he 'stands i' th' gaps' (4.4.8) of the tale: he is not in it, nor is the tale original to him, even though he tells it. This distance between narration and representation allows him to transport the action across space and time, directly calling on the audience's imagination: 'Thus time we waste and long leagues make short, / Sail seas in cockles, have and wish but for't / Making to take our imagination / from bourn to bourn, region to region' (4.4.1-4).

The distance Gower provides is analogous to the overview that the performance space of the Digby play affords, where the physical movement of actors between stations in the performance space helps the audience grasp the implications of the action. In both cases, the metadramatic dislocation enables the audience to grasp the structural underpinnings of the tale, but in Pericles, these underpinnings are narrative rather than spatial. Gower divides the narrative into episodes: he moves us from the incest at Antioch to the wooing of Thaisa, from Thaisa's supposed death and revival to Marina's 
preservation in the brothel, and from the reunion of father and daughter to that of husband and wife. He is not primarily concerned with establishing location, but with telling the tale. This priority is why, while his speeches move us around, we move just as frequently without his help: Gower shifts the locale six times, but it shifts seven times without his intervention. ${ }^{37}$ Obviously his intervention allows us to follow the tale, but he is a narrative anchor rather than a geographic one; he links the dramatized episodes together like illustrative slides or pageants in a medieval cycle.

The emblematic associations of the locales also help the audience envision the conceptual space of the play: like Mary Magdalen, Pericles has a moral topography as well as a geographic one. ${ }^{38}$ These emblematic associations help structure the play; unlike the saint's play, however, they are not embodied in the performance place, but associated with characters. These associations are connected to social or familial roles, and work through opposition and balance. Antioch is the place of the evil father, guilty of incest and murder, a place where sex equals death; it is opposed to Pentapolis, the home of the good father, a comic place where 'by loss of maidenhead / A babe is moulded' (3.0.10-11). Shakespeare similarly relates the nunnery of Ephesus and the brothel of Mytilene by opposition, stressed by the punning conflation of nun and whore in the period; Bolt and the Bawd, who threaten Marina, thus parody Cermion and Diana, who shelter Thaisa. Both spaces are connected with mothers: Ephesus is the place of the Goddess Diana, the 'good mother' who saves from death, and who is contrasted with both the Bawd, whose brothel consumes her foster children (4.2.13-14), and Dionyza. Similarly, the play links Tyre with the loyalty of Helicanus and Tarsus with the treachery of Cleon; each space has a moral marker, which helps clarify its role in the adventures of Pericles, Thaisa, and Marina, and helps connect it to the other spaces through which they pass. We may not have a clear understanding of the cities as geographic spaces, but we do have a clear mental map of their emblematic function; the moral topography and the narrative line Gower traces provide us with landmarks in the territory. We understand the play's travel on the play's characters: they serve to mark spaces and embody concepts that Pericles encounters in his wanderings in the world.

One final element which represents these wanderings is the set of dumb shows embedded in Gower's chorus speeches. The problem with representing travel on the platform stage is the difficulty of presenting movement: each scene can show a character leaving one location or arriving at another, but the movement of the actors between locations (which is built 
into place-and-scaffold staging) is extremely difficult to represent. Travel plays often use dumb shows to summarize events or voyages too cumbersome to stage. ${ }^{39}$ They are also old-fashioned, particularly when paired with verbal glosses, and thus are appropriate for Gower's archaic style. ${ }^{40}$ But Gower's shows are unusual: they are neither spectacular nor emblematic, nor do they summarize anything. The first shows the arrival of a messenger at Tarsus followed by Pericles's departure (2.0.16 sd); the second, the arrival of a messenger at Pentapolis followed by the departure of Pericles and Thaisa (3.0.14 sd); the last, Pericles arriving to mourn over Marina's tomb and departing 'in a mighty passion' (4.4.22 sd). These leave-takings are chosen over potentially spectacular events like the 'pompous marriage feast' (3.0.4) of Pericles and Thaisa. Moreover, they are not necessary: Gower could easily tell us of Pericles's departure instead. And they make the play longer, not shorter: Gower steps aside and lets us watch the shows - 'what need speak I?' (2.0.16) but then glosses the action of each in speeches of twenty to forty lines, in the last case, reading the long epitaph on Marina's grave. The dumb shows do none of the usual work of the form, and seem pointless.

What they do, though, is allow us to witness Pericles's departures. We see him leave three times; he enters with his hosts from one door, and leaves with his train from the other. In all cases, this simple performative gesture establishes the space he passes through: it's a way of setting location and moving locales without having to do so verbally. This technique is as close as Shakespeare's stage can get to actual representation of travel, and it gives us, gesturally, a sense of the character's constant motion. The mimed action also allows us to witness Pericles's grief at leave-taking, particularly in the third dumb show, where the departure encompasses the loss of Marina. The fact that all three dumb shows lead into the play's storms - the first two real, and the last metaphorical - suggests a further connection between physical departures and psychic suffering. We see in each one Pericles leaving a place where he has been at rest or at home, and moving back out into the uncertainty of the sea and into the crisis of the storms. We witness his displacement, and learn that it is associated with suffering. The dumb shows are pantomimes of loss. What is central to Pericles's movement is his emotional response to his travels, and ours to his sufferings.

This affective emphasis is the primary distinction between the spaces of Pericles and the Mary Magdalen: although space in both plays has emblematic status, the purposes of the protagonist's journeys within them are very different. In the Mary Magdalen the central relationship is that between the 
characters and God: God frames the action, God directs the travels of Mary and Marcylle, and the purpose of their wanderings in the world is to learn to trust the divine perspective. In Pericles, all the locales relate to familial and social roles, and the play has a fundamentally human scale. ${ }^{41}$ The climactic scene presents the 'reunited family as a restoration of wholeness and an expansion of being, a rebirth which is also a resurrection'. ${ }^{42}$ The parallel scene in the Digby play, Marcylle's reunion with his wife and child, is a good illustration of the difference between the two plays. After losing his wife and child, Marcylle does not mourn: he spends two years on pilgrimage in the holy land, being baptized by Peter, visiting 'the stacyons', and travelling to Nazareth and Bethlehem (1848-9), all of which implies that spiritual instruction is more important than the death of his wife. Likewise, the staging of the Queen's resurrection focuses on God's power: Marcylle prays over the bodies, asking the 'good Lord' his 'wyvys lyfe for to illumyn' (1894) and praising 'that puer vergyn' (1895) and 'the sonne of grace' (1897) for her revival. The family reunion is less important than the demonstration of divine power. Finally, the revived Queen rejoices, not that she is alive and reunited with her husband, but that she has been on a spiritual pilgrimage: she was 'wr[a]ppyd ... in wele from all waryawns / And led ... with my lord i[n]to the Holy Lond' (1903-4) where she has been baptized by Peter, seen the cross and the tomb, and 'gon the stacyounys' with her husband (1910). Spiritual instruction trumps the family reunion. The vast space of romance is embedded in the yet larger space of the divine will, a perspective the placeand-scaffold staging allows the audience to share.

In Pericles the audience shares Pericles's perspective, which is limited, narrow, and contingent; although Gower narrates the story, there is no god's-eye view that frames our vision. Chance and Fortune control the action, and beneficent Diana does not appear until the play's close. Pericles's tale is a story of human relations in a world of chance, into which the miraculous slowly intrudes to bring about the happy ending. For all the play's massive geographic range, its perspective is profoundly human, not divine. Its presentation on the unlocalized stage of the Globe serves to help the audience grasp the theme. If the place-and-scaffold space of Mary Magdalen is a physical representation of the world seen from heaven, then the unlocalized platform stage is much closer to the unmarked and shifting human perspective of an individual travelling through the world. Human life is necessarily as contingent and episodic as the treatment of space in this play. 
This line of analysis also explains the importance of the sea to Pericles, and its connection with loss and redemption. In Mary Magdalen all travel is pilgrimage, framed and directed by God and under his ultimate control; the world of the saint's play is void of chance. For Mary and the rulers of Marcylle, little difference separates sea and land, in that both are the space of pilgrimage and are represented by the platea, the space where Christ manifests himself. ${ }^{43}$ The holy land, sea, and wilderness are simply spaces in the world, which divine will controls: Mary is fed with manna by the angels, and the abandoned Queen is as safe on her sea-girt rock as Lazarus was in the tomb. But Pericles is a play of shipwreck, not pilgrimage. Chance in the form of the sea governs Pericles's travels, the sea an active element rather than the neutral space it is in the Mary Magdalen. The comfortingly divine perspective of the saint's play is not available to the audience of Pericles, who are driven and tossed from station to station along with the protagonist. The play's staging, which demands that the audience members build a map in their heads and then makes it extremely difficult for them to do so, seems a part of the play's design. Because we share Pericles's perspective, we also share his confusion and his sufferings; we follow his perils and comprehend their meaning, but only through contemplation after the wanderings are done.

\section{Notes}

1 Peter Holland, 'Coasting in the Mediterranean: The Journeyings of Pericles', Angles on the English-Speaking World 5 (2005), 20.

2 George Wilson Knight, The Crown of Life: Essays in Interpretation of Shakespeare's Final Plays (London, 1965), 36; Howard Felperin, 'Shakespeare's Miracle Play', Shakespeare Quarterly 18 (1967), 363-74 and Shakespearean Romance (Princeton, 1972); David Hoeniger, 'Introduction', Pericles, ed. David Hoeniger (London, 1963), lxxxviii-xcii; Peter Womack, 'Shakespeare and the Sea of Stories', Journal of Medieval and Early Modern Studies 29 (1999), 169-87; and Barbara Mowat, “'What's in a Name?” Tragicomedy, Romance or Late Comedy', Richard Dutton and Jean E. Howard (eds), A Companion to Shakespeare's Works, 4 vols (Oxford, 2006), 4.129-49.

3 For Gower's function as literary allusion and dramatic device see Richard Hillman, 'Shakespeare's Gower and Gower's Shakespeare: The Larger Debt of Pericles', Shakespeare Quarterly 36 (1985), 427-37; David Hoeniger, 'Gower and Shakespeare in Pericles', Shakespeare Quarterly 33 (1982), 461-97; Walter Eggers, Jr, 
'Shakespeare's Gower and the Role of the Authorial Presenter', Philological Quarterly 54 (1975), 434-43; Richard Paul Knowles, "Wishes fall out as they're will'd": Artist, Audience and Pericles's Gower', English Studies in Canada 9 (1983), 14-24; Stephen Lynch, Shakespearean Intertextuality (Westport, 1998); Kelly Jones, "The Quick and the Dead": Performing the Poet Gower in Pericles', Martha Driver and Sid Ray (eds), Shakespeare and the Middle Ages (Jefferson NC, 2009), 201-14. Paul Dean links Pericles with the tale of Jonah and Marina with St Margaret, a virgin martyr of Antioch, in 'Pericles' Pilgrimage', Essays in Criticism 50 (2000), 131-5. Mowat points out the debt of all four romances to the tale of St Eustace, the story of a family separated and reunited by fate ('What's', 136-9). Several critics discuss Marina's trial in the brothel at Mytilene in the context of the tales of St Agnes, St Daria, and St Anastasia, all protected in brothels by their supernatural purity; see Felperin, 'Miracle', 370; Lorraine Helms, 'The Saint in the Brothel: Or, Eloquence Rewarded', Shakespeare Quarterly 41.3 (1990), 323-5; Lynette R. Muir, Love and Conflict in Medieval Drama (Cambridge, 2007), 9-15. Note also the clear parallels between the Virgin Mary and Diana, the Great Mother goddess whom Thaisa serves as a vestal and who appears to Pericles in a vision; Suzanne Gossett, 'Introduction', Pericles, ed. Suzanne Gossett (London, 2004), 117-20.

4 The connections between the two plays are discussed by Mowat, 'What's', 135-43; Felperin, 'Miracle', 363-74; Hoeniger, 'Introduction', lxxxviii-xcii; and Womack, 'Sea', 169-72.

5 Ibid, 171. Work on the Digby Mary Magdalen widely acknowledges the interconnections between romance and saints' tales. Discussions of romance motifs in the play include Theresa Coletti, 'The Design of the Digby Play of Mary Magdalen', Studies in Philology 76 (1979), 313-33 and Mary Magdalen and the Drama of Saints: Theater, Gender, and Religion in Late Medieval England (Philadelphia, 2004), and Joanne Findon, 'Napping in the Arbour in the Digby Mary Magdalen Play', Early Theatre 9 (2006), 35-55.

6 For a survey of the textual and editorial problems of Pericles, see Gossett, 'Introduction', 10-54.

7 Hoeniger, 'Gower', 465; Gossett, 'Introduction', 70-6. John Gower, Confessio Amantis, ed. Russell A. Peck, trans. Andrew Galloway (Kalamazoo, 2000).

8 David Bevington, From Mankind to Marlowe (Cambridge MA, 1962); Robert Weimann and Robert Schwartz, Shakespeare and the Popular Tradition in the Theater: Studies in the Social Dimension of Dramatic Form and Function (Baltimore, 1978); Michael O'Connell, 'The Experiment of Romance', Alexander Leggatt (ed.), The Cambridge Companion to Shakespearean Comedy (Cambridge, 2002), 219. John Wasson makes specific connections between saints' plays and Renaissance drama 
in 'The Secular Saint Plays of the Elizabethan Era', Clifford Davidson and Clyde W. Brockett (eds), The Saint Play in Medieval Europe (Kalamazoo, 1986), 24160. Mowat also traces the connections between Shakespeare's late romances and 'dramas that trace back to the English miracle plays and then forward through the dramatic romances from Clyomon and Clamydes through Mucedorus' (Mowat, 'What's', 135).

9 A direct connection is impossible in any event: neither Shakespeare nor his collaborator, probably George Wilkins, could have read or seen Mary Magdalen. The play's final recorded performance was at Chelmsford in Essex in 1562 and the script did not leave the hands of the Chelmsford churchwardens until 1603. Gossett, 'Introduction', 62-70; John C. Coldewey, 'The Digby Plays and the Chelmsford Records', Research Opportunities in Renaissance Drama 18 (1975), 103-21.

10 William Shakespeare, Pericles, ed. Suzanne Gossett (London, 2004). All subsequent quotations are drawn from this edition.

11 Donald C. Baker, John L. Murphy, and Louis Brewer Hall (eds), 'Saint Mary Magdalen', The Late Medieval Religious Plays of Bodleian MSS Digby 133 and e Museo 160 (Oxford, 1982), 11. 1887-98. All subsequent quotations are drawn from this edition.

12 Jerome Bush, 'The Resources of Locus and Platea Staging: The Digby Mary Magdalen', Studies in Philology 86 (1989), 140-1. On the staging of the Digby play see Jacob Bennett, 'The Meaning of the Digby Mary Magdalen', Studies in Philology 101 (2004), 38-47; Joanne Findon, 'Napping', 35-55; D.K. Smith, “'to Passe the See in Shortt Space”: Mapping the World in the Digby Mary Magdalen', Medieval and Renaissance Drama in England 18 (2005), 193-214; and Chester Scoville, Saints and the Audience in Middle English Biblical Drama (Toronto, 2004).

13 Bush, 'Resources', 145.

14 Ibid, 161-3.

15 Ibid, 163.

16 Holland, 'Coasting', 11-16. There were several cities called Pentapolis in the ancient world, but, as Holland notes, none fits the play's geography; Linda McJannet suggests a cluster of five cities with names ending in '-polis' on the northern coast of the Aegean; McJannet, 'Genre and Geography: The Eastern Mediterranean in Pericles and The Comedy of Errors', John Gillies and Virginia Vaughan (eds), Playing the Globe: Genre and Geography in English Renaissance Drama (Madison, NJ, 1998), 86-106. Geography in Pericles is also discussed by John Gillies, 'Place and Space in Three Late Plays', A Companion to Shakespeare's Works, 4.176-7; Lisa Hopkins, “The Shores of My Mortality": Pericles' Greece of the Mind', David Skeele (ed.), Pericles: Critical Essays (New York, 2000), 228-37; and Constance C. Relihan, 'Liminal Geography: Pericles and the Politics of Place', Alison Thorne (ed.), New Casebooks: 
Shakespeare's Romances (Basingstoke, 2003), 71-90. McJannet argues that the play's political, cultural and geographic settings refer to 'a Hellenistic map of the ancient world' ('Genre and Geography', 96), while Relihan discusses the political implications of the play's contemporary near eastern geography. Gillies and Hopkins both see the play's spaces as emotional and psychic, not geographic, locales; Hopkins argues that Pericles is marked by 'an indifference to the particulars of location and atmosphere ... surprising in a play so centred on travel' (228).

17 The quarto text lacks act and scene divisions, which vary in modern editions; I use those of Gossett's Arden edition.

18 George Wilkins is the most probable candidate for Shakespeare's collaborator; for brevity's sake I will use 'Shakespeare' rather than 'Shakespeare and Wilkins'. For a discussion of authorship issues see Gossett, 'Introduction', 62-70.

19 Barbara Fuchs, Romance (New York, 2004), 23.

20 C.L. Barber and R. Wheeler, The Whole Journey: Shakespeare's Power of Development (Berkeley and Los Angeles, 1986), 310.

21 Holland, 'Coasting', 25.

22 Gillies, 'Place and Space', 183.

23 Pericles's performance history is discussed by Gossett, 'Introduction', 86-106, and by David Skeele, Thwarting the Wayward Seas (Newark, 1998). Skeele's collection Pericles: Critical Essays (New York, 2000) contains a valuable selection of performance reviews.

24 J.R. Mulryne, "To Glad Your Ear and Please Your Eye': Pericles at the Other Place', in Skeele, Pericles: Critical Essays, 292.

25 Dale Moffitt, 'Pericles and the Prospect Theatre', in Skeele, Pericles: Critical Essays, 278-87; Christine Dymkowski, “'Ancient [and Modern] Gower”: Presenting Shakespeare's Pericles', Philip Butterword (ed.), The Narrator, The Expositor and the Prompter in European Medieval Theatre (Turnhout, 2007), 258-64; Suzanne Gossett, “'Tell Thy Story”: Mary Zimmerman's Pericles', Shakespeare Quarterly 57 (2006), 184-5.

26 Gossett, 'Introduction', 95.

27 Melissa Gibson, 'Pericles at the Royal National Theatre', in Skeele, Pericles: Critical Essays, 333; Margaret Jane Kidnie, "'What world is this?": Pericles at the Stratford Festival of Canada, 2003', Shakespeare Quarterly 55 (2004), 307-19.

28 Gossett, 'Introduction', 98-99.

29 Peter Holland, “'Travelling hopefully”: The Dramatic Form of Journeys in English Renaissance Drama', Jean-Pierre Maquerlot and Michele Willems (eds), Travel and Drama in Shakespeare's Time (Cambridge, 1996), 160. Holland notes that most 
Renaissance travel plays use a chorus figure and narrate dumb shows to cut between locations and events.

30 Hoeniger, 'Gower', 463; Dymkowski, ““Ancient [and Modern] Gower”, 240.

31 Gossett, 'Introduction', 333 n.126.

32 Alan Dessen, Elizabethan Stage Conventions and Modern Interpreters (Cambridge, 1984), 39.

33 Wright, cited in Claire Preston, 'The Emblematic Structure of Pericles', Word and Image 8 (1992), 24 n.8.

34 The line echoes Richard's 'For God's sake, let us sit upon the ground, / And tell sad stories of the death of kings' (Richard II, 3.2.151-2). The Norton Shakespeare, ed. Stephen Greenblatt et al (New York, 2008).

35 Hillman, 'Shakespeare's Gower', 428.

36 Knowles, 'Wishes', 19.

37 Gower's speeches move us out of Tarsus into the storm (2.0), away from Pentapolis into the second storm (3.0), across fourteen years (4.0), from Tyre to Tarsus (4.4) to Myteline (5.0) and finally to Ephesus (5.2). Without his intervention, the action shifts from Antioch (1.1) to Tyre (1.2), from Tyre (1.2) to Tarsus (1.3), from Pentapolis (2.3) to Tyre (2.4); from the ship (3.1) to Ephesus (3.2), then to Tarsus (3.3) and back to Ephesus (3.4); and finally from Tarsus (4.1) to Myteline (4.2).

38 Emblematic locales are common in Shakespeare, and the romances, in particular, use setting this way: in The Winter's Tale the division between Sicilia and Bohemia clearly mirrors the play's tragic/comic division. Pericles is only unusual in the number of its settings.

39 Holland, 'Travelling', 165.

40 Hoeniger, 'Gower', 471.

41 Janet Adelman, Suffocating Mothers (New York, 1992) provides one of many readings of the play as 'family romance'.

42 Dean, 'Pericles' Pilgrimage', 138.

43 Bush, 'Resources', 145. 